\title{
Degradation changes stable carbon isotope depth profiles in palsa peatlands
}

\author{
J. P. Krüger ${ }^{1}$, J. Leifeld ${ }^{2}$, and C. Alewell ${ }^{1}$ \\ ${ }^{1}$ Environmental Geosciences, University of Basel, Basel, Switzerland \\ ${ }^{2}$ Agroscope Reckenholz-Tänikon Research Station ART, Zürich, Switzerland \\ Correspondence to: J. P. Krüger (janpaul.krueger@unibas.ch)
}

Received: 17 December 2013 - Published in Biogeosciences Discuss.: 22 January 2014

Revised: 5 May 2014 - Accepted: 16 May 2014 - Published: 24 June 2014

\begin{abstract}
Palsa peatlands are a significant carbon pool in the global carbon cycle and are projected to change by global warming due to accelerated permafrost thaw. Our aim was to use stable carbon isotopes as indicators of palsa degradation. Depth profiles of stable carbon isotopes generally reflect organic matter dynamics in soils with an increase of $\delta^{13} \mathrm{C}$ values during aerobic decomposition and stable or decreasing $\delta^{13} \mathrm{C}$ values with depth during anaerobic decomposition. Stable carbon isotope depth profiles of undisturbed and degraded sites of hummocks as well as hollows at three palsa peatlands in northern Sweden were used to investigate the degradation processes. The depth patterns of stable isotopes clearly differ between intact and degraded hummocks at all sites. Erosion and cryoturbation at the degraded sites significantly changes the stable carbon isotope depth profiles. At the intact hummocks the uplifting of peat material by permafrost is indicated by a turning in the $\delta^{13} \mathrm{C}$ depth trend, and this assessment is supported by a change in the $\mathrm{C} / \mathrm{N}$ ratios. For hollows isotope patterns were less clear, but some hollows and degraded hollows in the palsa peatlands show differences in their stable carbon isotope depth profiles indicating enhanced degradation rates. We conclude that the degradation of palsa peatlands by accelerated permafrost thawing can be identified with stable carbon isotope depth profiles. At intact hummocks $\delta^{13} \mathrm{C}$ depth patterns display the uplifting of peat material by a change in peat decomposition processes.
\end{abstract}

\section{Introduction}

Peatlands cover only $3 \%$ of the global land surface, but they are an important component in the global carbon (C) cycle (Joosten and Clarke, 2002; Yu et al., 2011). Most of the peatland carbon (between 450 and $700 \mathrm{Pg}$ ) is stored in the boreal and subarctic regions (Gorham, 1991; Yu et al., 2011; Jungkunst et al., 2012), so this region contains as much carbon as is currently stored in the atmosphere (Lal, 2008). Peatlands in the northern permafrost zone, where palsa mires are widespread, have accumulated more than $270 \mathrm{Pg}$ carbon in their soils (Tarnocai et al., 2009).

The existence of palsa mires is linked to climate conditions in the discontinuous permafrost region with low mean annual temperature, low annual precipitation and/or strong winds (Luoto and Seppälä, 2003; Luoto et al., 2004). On wind exposed sites with a thin or even lacking snow cover, a frozen core is built up (Luoto and Seppälä, 2002). The characteristics of palsa mires are mounds and plateaus called hummocks, which have been raised by the frozen core and thus lost connection to the groundwater. The uplifted peat surface above the surroundings leads to nutrient-poor and ombrotrophic conditions (Luoto et al., 2004). The wetter parts (hollows) between the hummocks or surrounding parts have a high water table with sometimes minerotrophic conditions. Palsa mires are growing peatlands with different stages of development (Seppälä, 2003). With increasing active layer depth (annual thawing soil layer), their hummocks lose stability and start to collapse at the edges by block erosion and subsidence (de Jong et al., 2010) and could create thermokarst ponds (Luoto and Seppälä, 2003). 
Global climate change with rising air temperatures particularly in the high latitudes leads to thawing of permafrost and an increase of the active layer thickness (Lemke et al., 2007; Åkerman and Johansson, 2008). In the Torneträsk region, northern Sweden, the active layer thickness has increased on average by 0.7 to $1.3 \mathrm{~cm}$ per year in the past 3 decades (Åkerman and Johansson, 2008). This process affects the hydrology, vegetation composition, $\mathrm{C}$ balance and other biogeochemical processes in the palsa peatlands (Christensen et al., 2004; Malmer et al., 2005; Bäckstrand et al., 2010; Olefeldt and Roulet, 2012). The degradation of palsa mires is likely to continue with the projected climate change, and the carbon exchange between the peatlands and the atmosphere will be altered (Dorrepaal et al., 2009; Schuur et al., 2009).

It is projected that in the next decades the palsa vegetation will shift from dry hummock to moist hummock due to permafrost thawing (Bosiö et al., 2012). This change impacts the carbon exchange of the mire with a decrease in the efflux of $\mathrm{CO}_{2}$ and an increase in the efflux of $\mathrm{CH}_{4}$, the sum of which is predicted to be equivalent to a slight decrease in $\mathrm{CO}_{2}$ equivalent emissions (Bosiö et al., 2012). Based on climate models it is estimated that the area suitable for palsa mires will decline by more than half by the 2030s, and likely all suitable areas will disappear by the end of 21 st century (Fronzek et al., 2006; de Jong et al., 2010; Fronzek et al., 2010).

Stable carbon isotopes are a widespread tool to analyse biochemical processes in soils. The ratio of ${ }^{12} \mathrm{C}$ and ${ }^{13} \mathrm{C}$ has been used to study soil degradation in different environments (oxic and wetland soils, Schaub and Alewell, 2009; palsa mires, Alewell et al., 2011). Depth profiles of stable carbon isotopes reflect organic matter dynamics (Krull and Retallack, 2000). The metabolic fractionation in plants produces slowly decomposing or recalcitrant substances like lignin which are low in ${ }^{13} \mathrm{C}$ (Benner et al., 1987; Ågren et al., 1996). On the other hand, decomposers used preferentially ${ }^{12} \mathrm{C}$ for respiration which might lead to an enrichment of ${ }^{13} \mathrm{C}$ in the remaining soil organic matter (Ågren et al., 1996; Alewell et al., 2011). As such, changes in metabolic pathways (aerobic to anaerobic) or reaction rates should alter stable carbon isotope signatures of soils. Based on a theoretical concept of $\delta^{13} \mathrm{C}$ in peatland soils outlined below, three main types of $\delta^{13} \mathrm{C}$ depth profiles were established and degradation hypotheses were developed.

The aim of this study was to use stable carbon isotope depth profiles as indicators of palsa degradation. Our hypotheses were as follows: (I) undisturbed palsa hummocks and degraded palsa hummocks differ significantly in their stable carbon isotope depth profiles. (II) A change from increasing to decreasing $\delta^{13} \mathrm{C}$ values at the intact hummocks indicates the uplifting of the hummocks by permafrost. (III) Degraded hollows show a higher variation of stable carbon isotopes in their depth profile compared to undisturbed hollows indicating degradation processes.

\section{Theoretical concept of $\delta^{13} \mathrm{C}$ in peatland soils}

The depth profiles of $\delta^{13} \mathrm{C}$ in soils which are not influenced by a change from $\mathrm{C} 3$ to $\mathrm{C} 4$ vegetation might be described by three main depth patterns (Fig. 1). The theoretical concept by Alewell et al. (2011) has been adapted to the two main soil types of our study - hummock (type A) and hollow (type B) of palsa peatlands. Additionally, the degraded status of both types is shown (type B and type C).

Depth profiles of intact hummocks (type A) are characterised by so-called "turning points" which indicate the uplifting of the hummocks by permafrost (Alewell et al., 2011). The $\delta^{13} \mathrm{C}$ signal increases in the upper part of the profile to a certain depth and then decreases to lower values. In the upper part mostly aerobic decomposition with preferential loss of ${ }^{12} \mathrm{C}$ compared to ${ }^{13} \mathrm{C}$ has increased the $\delta^{13} \mathrm{C}$ signal. Below this turning point the $\delta^{13} \mathrm{C}$ signal decreases with depth and shows a depth pattern similar to degraded hollows with anaerobic decomposition and an enrichment of recalcitrant material in the deeper parts.

Degraded hummocks show a uniform depth trend of $\delta^{13} \mathrm{C}$ (type B) or a zigzag pattern, because cryoturbation of hummock material mixed the soil material (Repo et al., 2009; Marushchak et al. 2011). The characteristic isotopic depth profile of intact hummocks has been merged to a constant signal lacking any depth trend in the soil profile.

A uniform depth trend is also found in intact hollows (type B) with little or no fractionation of $\delta^{13} \mathrm{C}$. This trend is characteristic of water-saturated soils (Clymo and Bryant, 2008) with low redox conditions and little time for decompositional fractionation to occur (Krull and Retallack, 2000). In peatland soils where methane could be produced, the opposite fractionation effects of $\mathrm{CO}_{2}$ and $\mathrm{CH}_{4}$ production resulted in a uniform depth trend of $\delta^{13} \mathrm{C}$ values (Clymo and Bryant, 2008). Another possibility is that the $\delta^{13} \mathrm{C}$ values of the source material (vegetation) have been preserved due to anoxic conditions in the peat and no isotopic fractionation occurred.

A trend to lower $\delta^{13} \mathrm{C}$ values with depth is found in degraded hollows (type C) with anaerobic composition. The decrease in $\delta^{13} \mathrm{C}$ values with depth is due to a relative enrichment of slowly decomposing substances depleted in ${ }^{13} \mathrm{C}$ (Benner et al., 1987). The degraded hollows are characterised by added hummock material which was eroded from the edges of the hummocks. The latter could increase degradation processes in the hollows and alter stable isotope depth profiles with an enrichment of recalcitrant material dominating the $\delta^{13} \mathrm{C}$ values (Benner et al., 1987; Alewell et al., 2011). The $\delta^{13} \mathrm{C}$ value decreases with depth and has lower values in the deeper part of the profile compared to the source material (vegetation signal). 

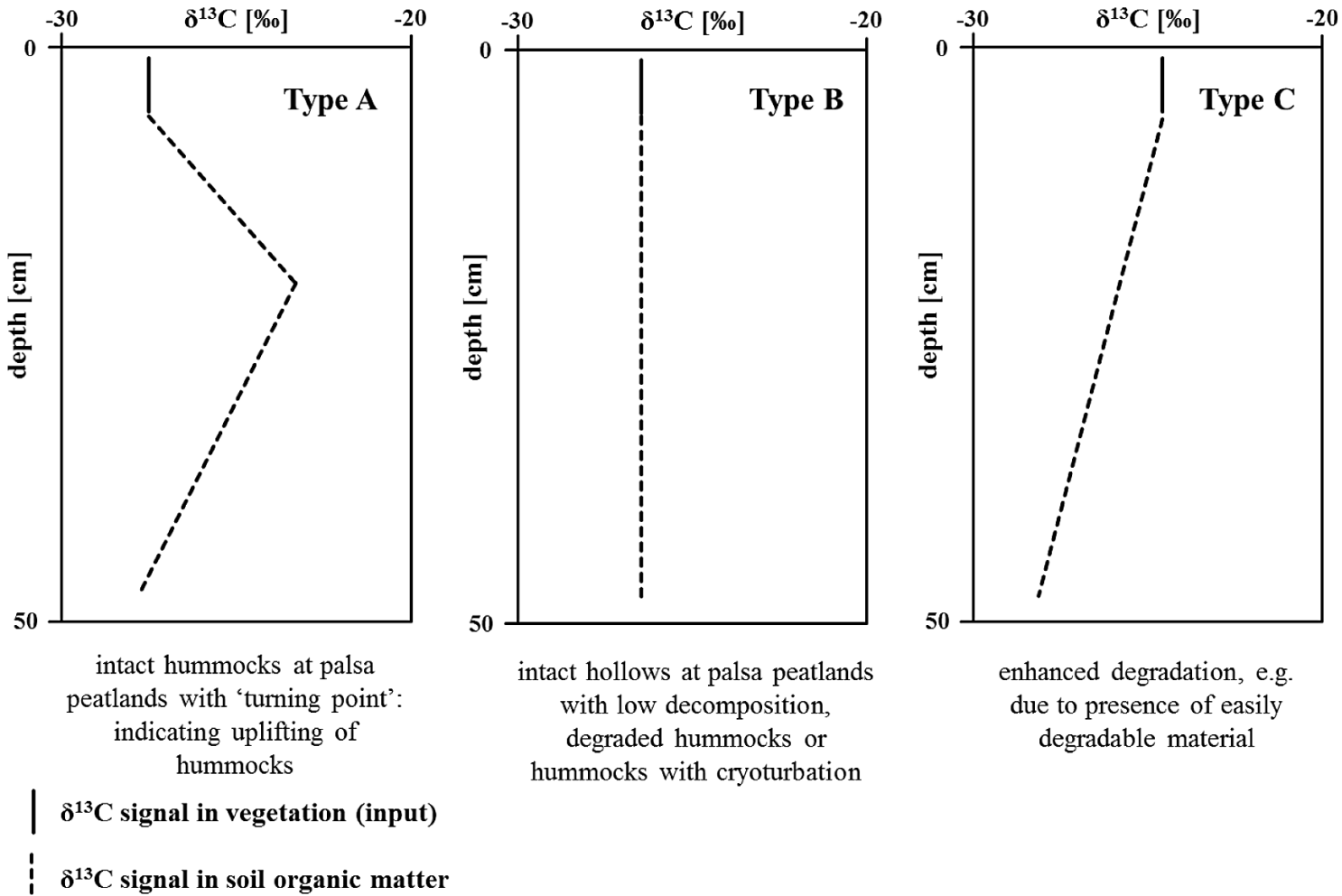

Figure 1. Theoretical concept depth profiles of ${ }^{13} \mathrm{C}$ in peatland soils with hummocks (type A), degraded hummocks (type B), hollows (type B) and degraded hollows (type C) (modified from Alewell et al., 2011).

\section{Material and methods}

\subsection{Sites}

We sampled three palsa peatlands which are situated in the Torneträsk valley near Abisko $\left(68^{\circ} 21^{\prime} \mathrm{N}, 18^{\circ} 49^{\prime} \mathrm{E}\right)$ in northern Sweden. The region is in the discontinuous permafrost zone $200 \mathrm{~km}$ north of the polar circle. Onset of peatland formation has been dated at ca. 4700 and ca. $6000 \mathrm{cal} \mathrm{BP}$ in the southern and northern part, respectively, of the Stordalen peatland (Kokfelt et al., 2010). All peatlands have drier, elevated parts with underlying permafrost called hummocks and adjacent, deeper and wetter parts called hollows. Permafrost aggradation was estimated to start at the peatlands in this region several hundred years ago (Malmer and Wallén, 1996; Kokfelt et al., 2010). The active layer, the annual thawing zone of the permafrost, usually reaches its greatest thickness in late September and is about 0.5 to $0.6 \mathrm{~m}$ deep at the hummocks and over $1.0 \mathrm{~m}$ in the hollows.

The Stordalen peatland (SD) is situated $10 \mathrm{~km}$ east of Abisko. A large part of the Stordalen peatland is a peat plateau elevated above the surrounding wet area. Malmer et al. (2005) classified three main plant communities, whereas Johansson et al. (2006) illustrate more site classes including the transition communities. In this study we focused on the elevated, dry hummock and on the wet hollow parts of the
Stordalen peatland. The dry palsa hummocks are dominated by dwarf shrub (e.g. Empetrum hermaphroditum) and lichens (Cetaria spp. and Cladonia spp.) (Olefeldt et al., 2012) and the wetter hollows by Sphagnum and Carex vegetation where the water table is close to the surface. Additional information of the sites, including defined species names, can be found in Malmer et al. (2005) and Johansson et al. (2006). In this peatland hummocks have a silt layer below the peat material. In some parts this layer starts already at $15-20 \mathrm{~cm}$ depth.

The Storflaket peatland (SF) is located about $3 \mathrm{~km}$ west of the Stordalen peatland, closer to Abisko between the road E10 and the railway. The peatland is also characterised by a dry palsa plateau with dwarf shrub (Empetrum nigrum) and lichen vegetation and with some wetter parts dominated by Sphagnum mosses (S. fuscum and S. balticum) (Lund et al., 2009 ) and Carex vegetation. A few cracks with block erosion along the edges are present. The peat plateau is surrounded by wet areas with tall graminoid vegetation and open water.

The Torneträsk peatland (TT) is situated in the Abisko valley $40 \mathrm{~km}$ east of Abisko between the road E10 and the lake Torneträsk. Large isolated palsas (up to $1.5 \mathrm{~m}$ ) with dwarf shrub (Empetrum nigrum) and lichen vegetation and with Sphagnum and Carex vegetation in between characterise this peatland. The palsas are small domeshaped palsas with strong degradation on the edges with cracks and block erosion. 


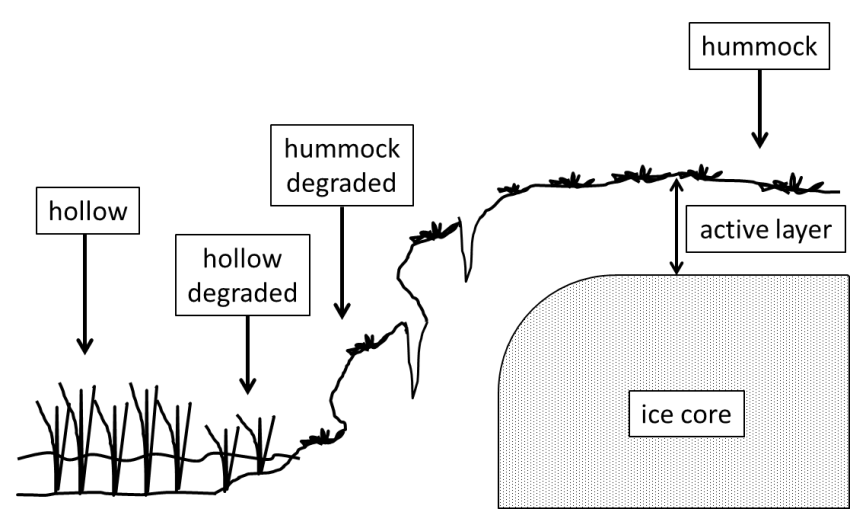

Figure 2. Transect of the sampling at the palsa peatlands with an approximately distance of $4.0-8.0 \mathrm{~m}$ between the outer sampling points.

\subsection{Climate}

Climate data are recorded since 1913 at the Abisko Research Station with a mean annual air temperature of $-0.6^{\circ} \mathrm{C}$ and mean annual precipitation of $304 \mathrm{~mm}$ for the period $1913-$ 2003. The precipitation at the two peatlands Stordalen and Storflaket does not differ significantly from the climate station (Johansson et al., 2006). Annual precipitation at Torneträsk is with $476 \mathrm{~mm}$ higher compared to the two other peatlands (Åkerman and Johansson, 2008). For the period 1961-1990 mean annual temperature is $0.2^{\circ} \mathrm{C}$ lower at Torneträsk compared to Stordalen and Storflaket (Åkerman and Johansson, 2008).

\subsection{Peat samples}

Peat cores were collected at the three palsa peatlands from September to October 2012. Samples were taken in small transects (Fig. 2) from hummock (hu) to hollow (ho) with degraded hummock (hud) and degraded hollow (hod) in between. We defined undisturbed hummocks as elevated palsas with no visible cracks or erosion. In contrast, degraded hummocks show clear cracks and erosion and are situated mainly at the edges of the palsas with partly water-saturated soil, but with typical hummock vegetation (dwarf shrub and lichen). Undisturbed hollows are represented by water-saturated parts of the peatlands with no influence of hummocks and their eroded material. Degraded hollows are hollows influenced by the eroded hummock material close to the degraded hummocks, but with distinct hollow vegetation (Sphagnum and Carex). Each of these transect sites are represented by three cores $(n=3)$. Samples of palsa peatlands were taken with a Russian peat auger (Eijkelkamp, Netherlands) or with a cylindrical soil auger (Giddings Machine Company, US) down to the permafrost (hummocks) or about $0.5 \mathrm{~m}$ deep (hollows). The peat cores were embedded in plastic shells, wrapped with plastic foil and transported directly to the lab. Cores were cut into 0.02 to $0.04 \mathrm{~m}$ sections in the lab and oven-dried at $40-50{ }^{\circ} \mathrm{C}$ for $72 \mathrm{~h}$. The procedure was done on the day of sampling. Samples were transported and stored until preparing for drying at air temperature, but peat was dried directly after sampling. All samples were ground and homogenised in a vibrating ball mill (MM 400, Retsch, Germany). Stable carbon isotopes, organic $\mathrm{C}$ and total $\mathrm{N}$ concentrations were measured with isotope ratio mass spectrometer (Thermo Finnigan Delta plus XP coupled with a Flash EA 1112 Series elemental analyser; both instruments supplied by Thermo-Finnigan, Waltham, MA, USA) following standard processing techniques. Stable carbon isotope ratios are reported as $\delta^{13} \mathrm{C}$ in [\%o] relative to the V-PDB standard. The instrumental standard deviation for $\delta^{13} \mathrm{C}$ is $0.1 \%$. The $\mathrm{C} / \mathrm{N}$ ratio represents the atomic relationship between carbon and nitrogen content of the peat material. Active layer depth was determined at hummocks manually by a $1 \mathrm{~cm}$ diameter steel rod inserted into the soil. Measurements were done in late September-early October, which is the time of maximum thaw of the permafrost.

\section{Results and discussion}

Stable carbon isotope values of peat profiles from the three palsa peatlands in all studied sites varied between $-21.2 \%$ and $-29.1 \%$ and are in the range of other peatland studies (e.g. Price et al., 1997; Hornibrook et al., 2000; Menot and Burns, 2001; Jones et al., 2010; Alewell et al., 2011; Andersson et al., 2012; Broder et al., 2012; Esmeijer-Liu et al., 2012). However, the different sites at the palsa peatlands showed distinct depth profiles of stable carbon isotopes indicating different processes during peat accumulation and decomposition.

\subsection{Hummocks}

Eight out of nine hummocks show a depth pattern of $\delta^{13} \mathrm{C}$ with a turning point, i.e. a profile with an increase of $\delta^{13} \mathrm{C}$ in the upper part and a decrease to lower ${ }^{13} \mathrm{C}$ values in the deeper part with the lowest measured $\delta^{13} \mathrm{C}$ value in the profile at the turning point (Fig. 3). Regression analysis indicates a clear (in some profiles a significant) change from increase to decrease of $\delta^{13} \mathrm{C}$ values with depth (Table 1).

The turning point depth varies between the three peatlands from lowest depth at Stordalen (about $6 \mathrm{~cm}$ ) to medium at Storflaket (between 11 and $31 \mathrm{~cm}$ ) and deepest at Torneträsk (22 to $41 \mathrm{~cm}$ depth). The $\delta^{13} \mathrm{C}$ signal at turning points in all peatlands is approximately $-25.0 \%$. Based on the peat accumulation rates determined in Alewell et al. (2011), the age of the turning points in this study is about 120 years at Stordalen, between 200 and 580 years at Storflaket and up to almost 800 years at Torneträsk (Table 1). The turning point ages are comparable to ${ }^{14} \mathrm{C}$ dated ages in Alewell et al. (2011) of 155-671 years for Stordalen and Storflaket. Thus, the Suess effect played a minor role in the palsa peat 
Table 1. Regression analyses of $\delta^{13} \mathrm{C}$ and depth at hummocks (hu) and hummocks (hud) degraded of the peatlands Stordalen (SD), Storflaket (SF) and Torneträsk (TT) with "turning points" and calculated ages of the "turning points".

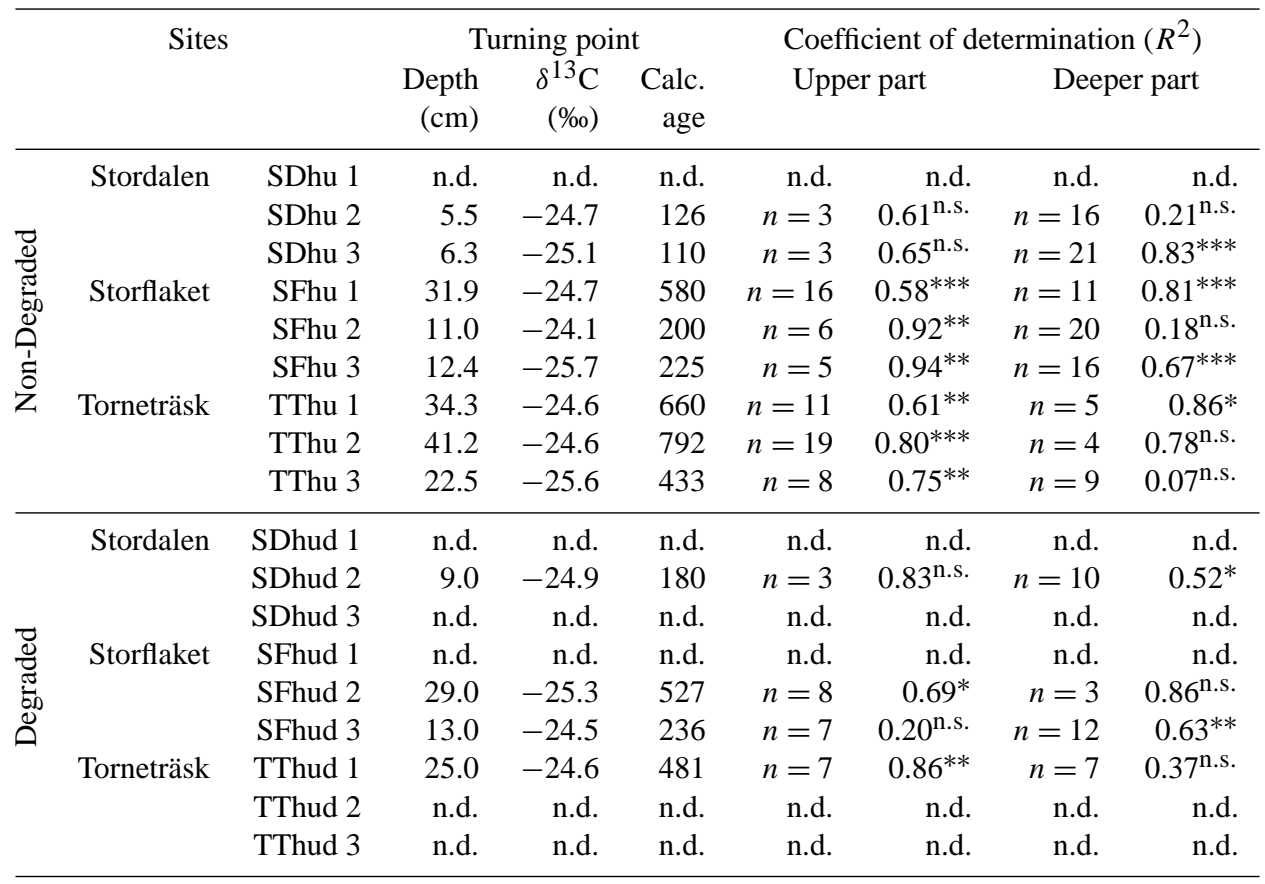

n.s. $=$ not significant, ${ }^{*} p<0.05,{ }^{* *} p<0.01,{ }^{* * *} p<0.001$, n.d. $=$ not detected, calc. age (years) $=$ age calculated based on results from Alewell et al. (2011), with mean peat accumulation rates for Stordalen $\left(0.5 \mathrm{~mm} \mathrm{yr}^{-1}\right)$ and Storflaket

$\left(0.55 \mathrm{~mm} \mathrm{yr}^{-1}\right)$ and mean of both peatland for Torneträsk $\left(0.52 \mathrm{~mm} \mathrm{yr}^{-1}\right)$ peatland.

profiles, because the turning points are much older and it will only be documented in the upper centimetre of the profile (Alewell et al., 2011). The increase of $\delta^{13} \mathrm{C}$ with depth is comparable to well-drained soils where aerobic decomposition favours selective loss of ${ }^{12} \mathrm{C}$ (Nadelhoffer and Fry, 1988). The change from minerotrophic to ombrotrophic conditions of the Stordalen mire, which are caused by the uplift of the palsas due to permafrost, is supposed to have occurred also in the time period mentioned above (Rydberg et al., 2010). In line with our results at Stordalen peatland (turning point ca. 120 years), Kokfelt et al. (2010) detected palsa formation at the Stordalen site at ca. 120 cal BP. However, permafrost aggradation started at Stordalen over 800 years ago, and since then ombrotrophic conditions have dominated the peatland (Malmer and Wallén, 1996). The differences in turning point ages between the three sites may indicate different times of the uplifting of the palsas and a shift from anaerobic to aerobic decomposition. Small-scale differences in climate conditions (precipitation, temperature, wind exposure) could lead to different timing of permafrost uplift. In view of palsa formation, the higher age of the turning points at Torneträsk peatland compared to the two other peatlands could be explained by an earlier uplifting of the hummocks and is congruent with the formation of considerably bigger hummocks. Simultaneously the visible advanced degradation of the palsas at Torneträsk indicates a collapsing palsa and a higher development status of the palsa peatland (Seppälä, 2006), which might be explained by an advanced influence from climate change in this region.

All profiles, with one exception, show highest $\mathrm{C} / \mathrm{N}$ ratios in the upper 10 to $15 \mathrm{~cm}$ (Fig. 3), which is congruent with the results from Rydberg et al. (2010). They investigated a core at Stordalen peatland with a change from ombrotrophic to minerotrophic conditions at about $15 \mathrm{~cm}$ depth. $\mathrm{C} / \mathrm{N}$ ratio decreases at this depth from high to lower values. Kokfelt et al. (2010) measured high $\mathrm{C} / \mathrm{N}$ ratios in the uppermost part and even higher in the sequence just below. In the deeper sequences they detected low $\mathrm{C} / \mathrm{N}$ ratios, which is congruent with our results. From the eight hummocks showing a turning point, seven have highest $\mathrm{C} / \mathrm{N}$ ratios at or above the turning point, indicating ombrotrophic conditions. In contrast, low $\mathrm{C} / \mathrm{N}$ ratios in peatlands indicate minerotrophic conditions (Andersson et al., 2012), and therefore this change at the turning points could be another indicator of the uplifting of hummocks by permafrost. The absentee change in $\mathrm{C} / \mathrm{N}$ ratios from high to lower values at Torneträsk peatland may indicate that the Torneträsk peatland was not strongly influenced by groundwater, and therefore no minerotrophic conditions occurred (Broder et al., 2012).

Low $\mathrm{C} / \mathrm{N}$ ratios are in parallel with low $\delta^{13} \mathrm{C}$ values and vice versa (Fig. 3). All sites show a positive correlation between $\delta^{13} \mathrm{C}$ and $\mathrm{C} / \mathrm{N}$ ratios (Table 2) although the strength 
Table 2. Correlation between $\delta^{13} \mathrm{C}$ and $\mathrm{C} / \mathrm{N}$ ratio with correlation coefficient and error probability at hummocks in the three palsa peatlands.

\begin{tabular}{llrrr}
\hline \multirow{2}{*}{ sites } & & $n$ & $r$ & $p$ \\
\hline \multirow{4}{*}{ Stordalen } & SDhu 1 & 6 & 0.84 & 0.11 \\
& SDhu 2 & 19 & 0.75 & 0.00 \\
& SDhu 3 & 23 & 0.75 & 0.00 \\
Storflaket & SFhu 1 & 26 & 0.08 & 0.45 \\
& SFhu 2 & 25 & 0.78 & 0.00 \\
& SFhu 3 & 20 & 0.41 & 0.00 \\
Torneträsk & TThu 1 & 15 & 0.31 & 0.44 \\
& TThu 2 & 22 & 0.54 & 0.02 \\
& TThu 3 & 16 & 0.27 & 0.42 \\
\hline
\end{tabular}

of correlation varies. A correlation between $\mathrm{C} / \mathrm{N}$ ratios and ${ }^{13} \mathrm{C}$ values in peat soils was also found by Hornibrook et al. (2000). A close correlation indicates that decomposition is driving the stable isotope values (Jones et al., 2010). However, Esmeijer-Liu et al. (2012) found no correlation between $\mathrm{C} / \mathrm{N}$ and ${ }^{13} \mathrm{C}$ values in a peat core. In forest soils values of $\delta^{13} \mathrm{C}$ were mostly low in more strongly decomposed soil, because decomposition processes favour selective loss of ${ }^{12} \mathrm{C}$ and an enrichment of ${ }^{13} \mathrm{C}$ in the remaining material (Nadelhoffer and Fry, 1988). The correlation of organic matter C/N ratios and decomposition processes has been shown in other studies with a relatively higher loss of peat carbon compared to nitrogen during decomposition (Malmer and Holm, 1984; Kuhry and Vitt, 1996).

Mean active layer depth at hummocks is greatest at Stordalen $(58 \mathrm{~cm})$, less deep at Storflaket $(52 \mathrm{~cm})$ and shallowest at Torneträsk $(49 \mathrm{~cm})$ peatland. In contrast, in a previous study in 2008 mean active layer thickness was shallower at Stordalen $(50 \mathrm{~cm})$ compared to Torneträsk $(56 \mathrm{~cm})(\mathrm{Keu}-$ per et al., 2012). Either the Torneträsk palsas have been subsided and the active layer depth has decreased or Stordalen has been degrading faster recently. Another possibility is that the absolute thawing depth and relative differences are an annual fluctuating phenomenon (Åkerman and Johansson, 2008).

\subsection{Degraded hummocks}

In comparison to intact hummock profiles, most of the degraded hummocks show no clear depth pattern such as a turning point or a change from increasing $\delta^{13} \mathrm{C}$ values to decreasing $\delta^{13} \mathrm{C}$ values with depth (Fig. 4). The majority of depth profiles of degraded hummocks show a uniform depth trend or a zigzag pattern of $\delta^{13} \mathrm{C}$ without clear direction. However, some of the degraded hummocks show a similar depth pattern in their $\delta^{13} \mathrm{C}$ values with a turning point (Table 1) similar to the intact hummocks (SDhud2, SFhud2, SFhud3, TThud1). The uniform depth pattern could indi- cate the degradation of former intact hummocks caused by cryoturbation of the peat material. Continued warming in the Arctic could accelerate cryoturbation (Repo et al., 2009; Marushchak et al., 2011) and hence increase degradation processes of palsa peatlands. Aerobic decomposition in palsa peatlands leads to selective preservation of recalcitrant and oxidised C in the soil organic matter (Pengerud et al., 2013). Advanced degradation of palsa hummocks leads to a transport of recalcitrant material into the surrounding hollows. The pattern in the degraded hummock profiles which are similar to those of intact hummocks may be related to a recent degradation of these areas and until now with no degradation signs in the $\delta^{13} \mathrm{C}$ profile. The two intact depth profiles at the Storflaket peatland at visibly degraded sites could indicate the recent degradation at this palsa peatland with no change in the isotope signal until now. The recent degradation is supported by a previous study of Klaminder et al. (2008), who found no degradation at the Storflaket peatland 5 years ago.

At the Stordalen peatland the influence of the underlying silt layer can be seen in two out of three profiles with very low $\mathrm{C}$ content (below $20 \%$ ) and higher bulk density (up to $0.5 \mathrm{~g} \mathrm{~cm}^{-3}$ ) in the deepest parts of the profile. This supports the cryoturbation consideration indicated by the homogeneous $\delta^{13} \mathrm{C}$ depth pattern. The underlying organic-rich silt layer refers to permafrost-free conditions and was dated ca. 2800 cal BP (Kokfelt et al., 2010).

Degraded hummock profiles have low $\mathrm{C} / \mathrm{N}$ ratios (on average $12-27 \%$ lower than intact hummocks) especially in their deeper parts $(\mathrm{C} / \mathrm{N}$ ratio $<20)$ with the exception of the degraded hummocks at Torneträsk. Various studies have shown that the $\mathrm{C} / \mathrm{N}$ ratio is lower in more strongly decomposed peat (e.g. Malmer and Holm, 1984; Kuhry and Vitt, 1996), because nitrogen is relatively enriched compared to carbon. In N-limited ecosystems, such as peatlands, decomposition leads to a relatively higher loss of $\mathrm{C}$ compared to $\mathrm{N}$, because organisms respiring organic substances will retain the $\mathrm{N}$ in the systems. Low $\mathrm{C} / \mathrm{N}$ ratios in cryoturbated peatlands were also found by Repo et al. (2009) because of significantly higher nitrogen content (about $2 \%$ ) compared to typical peat plateaus and likely a higher decomposition rate. The latter is supported by higher respiration rates of incubated peat material at degraded sites compared to intact sites (Turetsky, 2004; Pengerud et al., 2013).

\subsection{Hollows}

Most of the hollows at the three palsa peatlands show a quite uniform depth trend of $\delta^{13} \mathrm{C}$ with low variation of $\delta^{13} \mathrm{C}$ (Fig. 5). In six out of nine depth profiles, the variation coefficient of $\delta^{13} \mathrm{C}$ values is very low (Table 3 ) indicating uniform depth patterns. Uniform depth patterns are characteristic of water-logged soils, such as peatland soils, with little time for soil formation and/or limited decompositional fractionation (Krull and Retallack, 2000; Clymo and Bryant, 2008). Such conditions preserve the original isotopic signature (Krull and 
Table 3. Coefficient of variation $(\mathrm{CV})$ of $\delta^{13} \mathrm{C}[\%$ ] at hollows and degraded hollows.

\begin{tabular}{|c|c|c|c|c|c|c|c|c|c|c|c|c|c|c|c|c|c|c|}
\hline & \multicolumn{6}{|c|}{ Stordalen } & \multicolumn{6}{|c|}{ Storflaket } & \multicolumn{6}{|c|}{ Torneträsk } \\
\hline & \multicolumn{3}{|c|}{ non-degraded } & \multicolumn{3}{|c|}{ degraded } & \multicolumn{3}{|c|}{ non-degraded } & \multicolumn{3}{|c|}{ degraded } & \multicolumn{3}{|c|}{ non-degraded } & \multicolumn{3}{|c|}{ degraded } \\
\hline & hol & ho2 & ho3 & hod1 & hod2 & hod3 & ho1 & ho 2 & ho3 & hod1 & hod2 & hod3 & ho1 & ho 2 & ho3 & hod1 & hod2 & hod3 \\
\hline$n$ & 9 & 8 & 9 & 25 & 20 & 23 & 14 & 9 & 21 & 10 & 11 & 20 & 7 & 6 & 7 & 9 & 12 & 12 \\
\hline $\mathrm{CV}(\%)$ & 2.2 & 2.3 & 5.7 & 5.1 & 4.4 & 2.0 & 2.3 & 5.7 & 3.8 & 3.6 & 2.8 & 3.2 & 1.8 & 0.7 & 2.7 & 4.8 & 8.0 & 7.9 \\
\hline
\end{tabular}
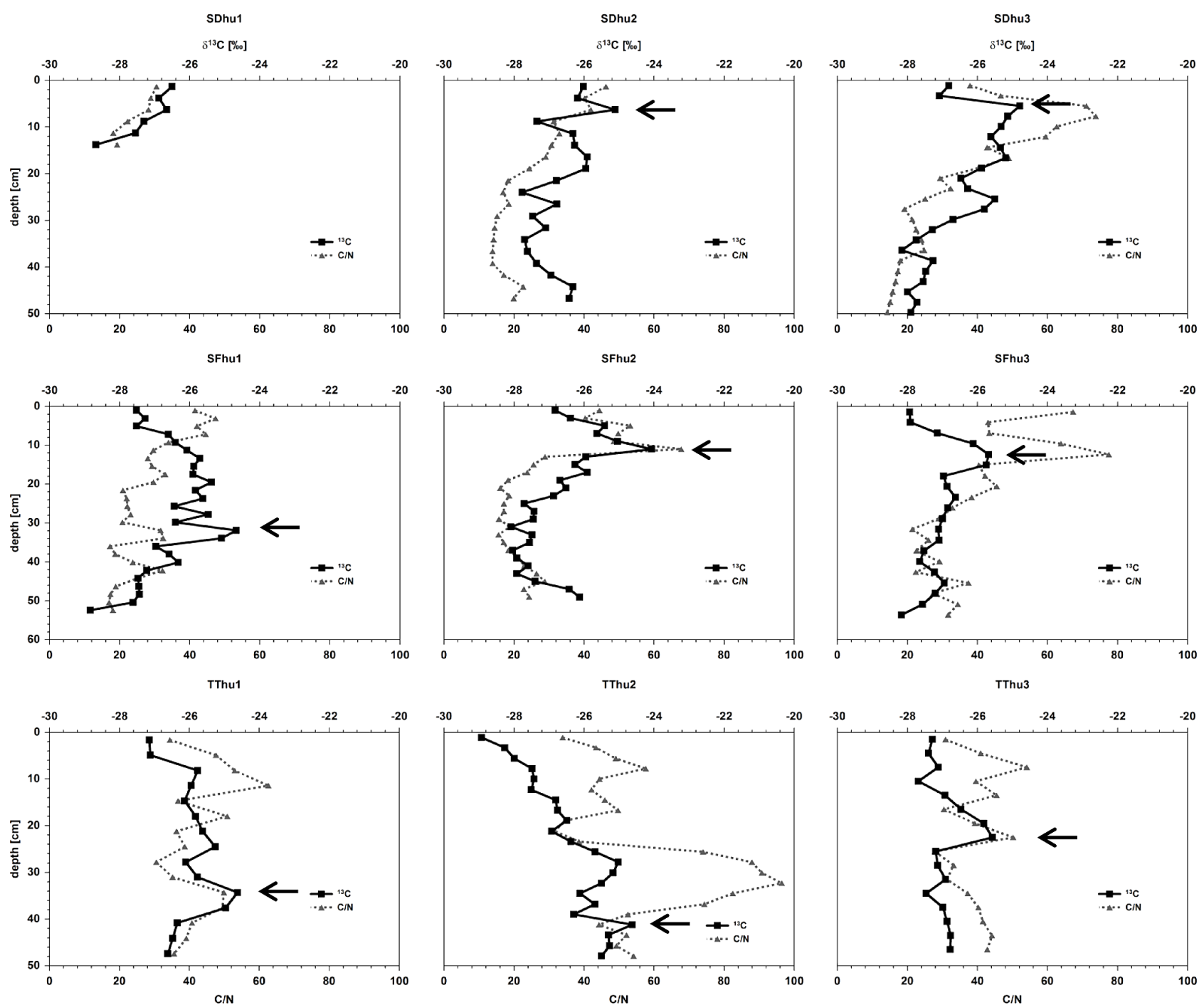

Figure 3. $\delta^{13} \mathrm{C}$ and $\mathrm{C} / \mathrm{N}$ ratio in depth profiles of hummocks (hu) at Stordalen (SD), Storflaket (SF) and Torneträsk (TT) peatland. Turning points in the profiles are indicated with black arrows.

Retallack, 2000). Opposite fractionation effects of $\mathrm{CO}_{2}$ and $\mathrm{CH}_{4}$ formation in peatlands under low redox conditions with methane production may also result in a uniform depth trend of $\delta^{13} \mathrm{C}$ in the remaining material (Clymo and Bryant, 2008).

One of the hollows at Storflaket (SFho2) has a depth pattern comparable to the degraded hollow profiles with decreasing $\delta^{13} \mathrm{C}$ values with depth (see degraded hollows). Two profiles (SDho3 and SFho3) show an increase to heavier sig- natures with depth indicating slow aerobic decomposition in the hollows (Krull and Retallack, 2000; Alewell et al., 2011).

In some profiles $\mathrm{C} / \mathrm{N}$ ratios peak at $10-15 \mathrm{~cm}$ depth. This indicates the accumulation of fresh, little decomposed organic material (Kuhry and Vitt, 1996). C/N ratios at Torneträsk peatland are particularly high with values around 100 , an indicator of strong ombrotrophic conditions (Andersson et al., 2012). In general, the hollow profiles show higher 

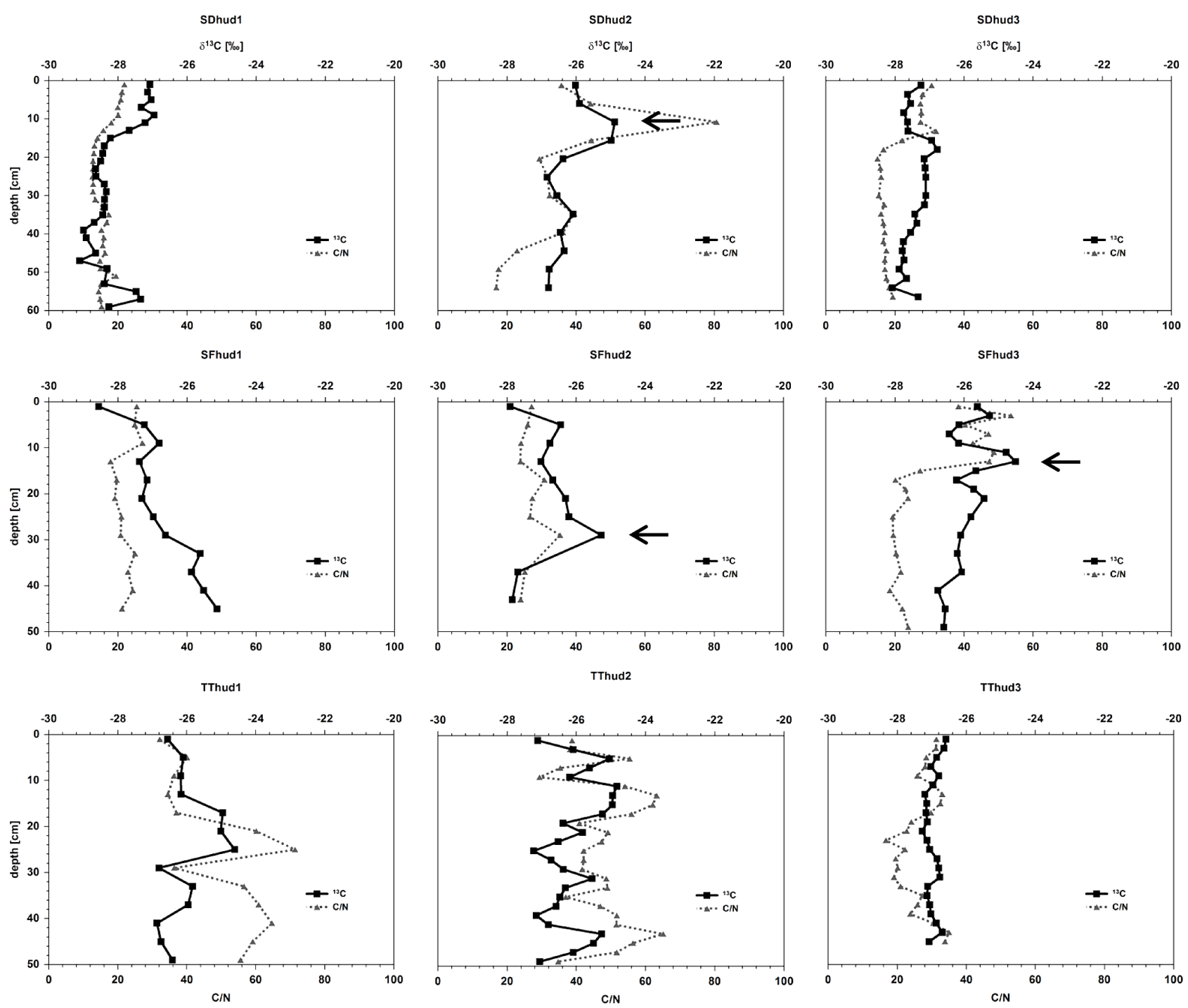

Figure 4. $\delta^{13} \mathrm{C}$ and $\mathrm{C} / \mathrm{N}$ ratio in depth profiles of degraded hummocks (hud) at Stordalen (SD), Storflaket (SF) and Torneträsk (TT) peatland. Turning points in the profiles are indicated with black arrows.

$\mathrm{C} / \mathrm{N}$ ratios compared to the degraded hollows, indicating that the peat material is less decomposed.

\subsection{Degraded hollows}

Degraded hollows at Torneträsk peatland show a decreasing depth pattern in the upper part congruent with the depth profile of type C (Fig. 6) and a uniform depth trend in deeper layers (type B). These profiles of Torneträsk peatland indicate an anaerobic degradation of the degraded hollow sites with significant differences in the stable isotope depth pattern compared to the intact hollows. Two profiles at Stordalen (SDhod1, SDhod2) show a similar depth pattern like the degraded hollows at Torneträsk. This could be due to the ongoing accelerated degradation of these palsa peatlands. However, at Storflaket no clear depth pattern of $\delta^{13} \mathrm{C}$ at degraded hollows was found. The missing clear depth pattern at Storflaket could be due to low degradation of the palsa peatland and the hollows until now. Klaminder et al. (2008) detected no degradation in their study at Storflaket, whereas Alewell et al. (2011) found low degradation. In 2012 we found visible degradation with cracks and block erosion on the edges at this palsa peatland. However, this recent degradation of the hummocks might not be imprinted in the stable isotopes yet. The variation coefficient of $\delta^{13} \mathrm{C}$ values at degraded hollows compared to intact hollows (Table 3 ) is higher at Torneträsk peatland indicating larger variability of $\delta^{13} \mathrm{C}$ values and advanced degradation processes in these hollows. No significant higher variation coefficients at degraded hollows were found at Stordalen and Storflaket peatland.

In the degraded hollows the metabolic fractionation in plants may produce recalcitrant substances low in ${ }^{13} \mathrm{C}$ 

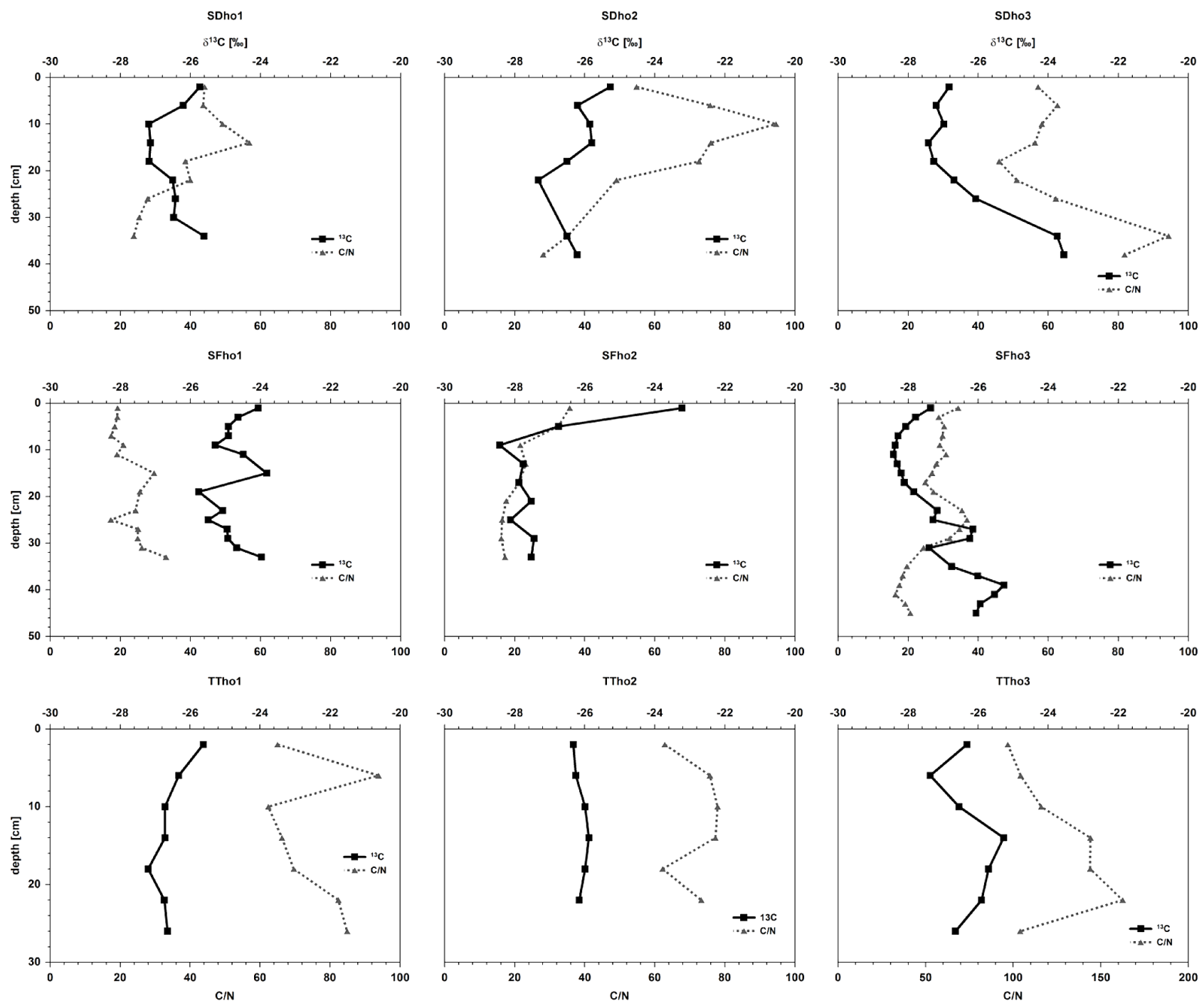

Figure 5. $\delta^{13} \mathrm{C}$ and $\mathrm{C} / \mathrm{N}$ ratio in depth profiles of hollows (ho) at Stordalen (SD), Storflaket (SF) and Torneträsk (TT) peatland.

(Benner et al., 1987; Ågren et al., 1996). Owing to the high water table and probably permanent anoxic condition, the decomposition of organic matter is low. Therefore, the associated fractionation process with the preferential use of ${ }^{12} \mathrm{C}$ for respiration by decomposers and an enrichment of ${ }^{13} \mathrm{C}$ during decomposition is limited (Ågren et al., 1996). These degraded hollows are particularly affected by the (block) erosion of the thawing hummock. The additional hummock material could increase degradation rates in the hollows with a stronger accumulation of recalcitrant material depleted in ${ }^{13} \mathrm{C}$ in the deeper layers (Alewell et al., 2011) and thus explain the different $\delta^{13} \mathrm{C}$ depth patterns between degraded and intact hollows. In the deeper parts the isotope signal is similar to that of the undisturbed hollows. Hollows contain a significant amount of labile $\mathrm{C}$ currently stabilised by anaerobic conditions (Pengerud et al., 2013). With degradation of palsas additional peat material is transported from hummocks into hollows and could alter the oxygen conditions and hence the decomposition processes in the hollows.

\section{Conclusions}

In the studied palsa peatlands, depth profiles of stable carbon isotopes show typical patterns related to their metabolism and degree of degradation. A changing climate in this region with continuous permafrost thawing altered the topography of the palsa peatlands, which induced a change in isotope depth profiles.

(I) The $\delta^{13} \mathrm{C}$ depth profiles of hummocks differ significantly from the degraded hummocks. All but one intact hummock show a depth pattern with an isotopic turning point, i.e. change from increasing to decreasing $\delta^{13} \mathrm{C}$ values. Most of the degraded hummocks have no 

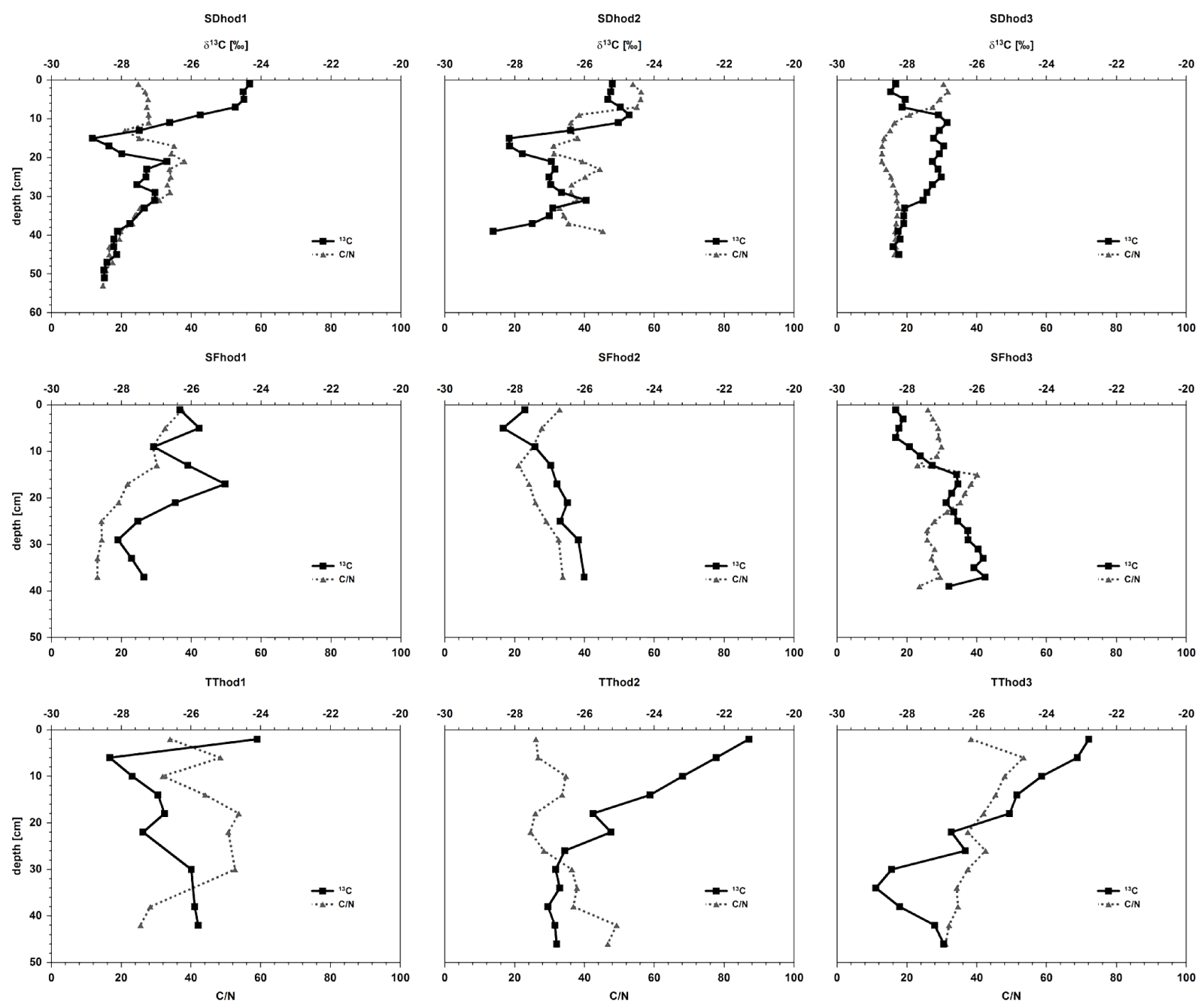

Figure 6. $\delta^{13} \mathrm{C}$ and $\mathrm{C} / \mathrm{N}$ ratio in depth profiles of degraded hollows (hod) at Stordalen (SD), Storflaket (SF) and Torneträsk (TT) peatland.

turning point and display a more or less uniform depth profile of $\delta^{13} \mathrm{C}$ indicating degradation and cryoturbation processes in these areas.

(II) The change from increasing to decreasing $\delta^{13} \mathrm{C}$ values at hummocks indicates most likely the time of uplifting of the hummocks by permafrost above the surrounding areas with aerobic decomposition in the upper and anaerobic decomposition in the deeper part. The hypothesis of uplifting is supported by the higher $\mathrm{C} / \mathrm{N}$ ratios above the turning point and lower values below, indicating ombrotrophic and minerotrophic conditions, respectively.

(III) Five out of six degraded hollows at two palsa peatlands show a predicted depth pattern of degraded hollows. $\delta^{13} \mathrm{C}$ values at degraded hollows decrease with depth indicating an accumulation of recalcitrant material with depth as an indicator of anaerobic degradation in these peatlands. No clear differences were found at the Storflaket peatland, which might be due to the more recent influence of degradation.

A degradation of hollows in the palsa peatlands with altered decomposition conditions is indicated by the $\delta^{13} \mathrm{C}$ in some of the profiles. $\delta^{13} \mathrm{C}$ depth profiles of palsa peatlands in the hummock parts show the patterns of our established hypothesis of palsa degradation.

The Supplement related to this article is available online at doi:10.5194/bg-11-3369-2014-supplement. 
Acknowledgements. The research leading to these results has received funding from INTERACT (grant agreement no. 262693) under the European Community's Seventh Framework Programme. The Climate Impacts Research Center (CIRC, Sweden), particularly Reiner Giesler, and the Abisko Research Station (ANS, Sweden) supported this study. This work was financed by the Swiss National Foundation (SNF), project no. 200021-137569. We thank Axel Birkholz and Mark Rollog for stable isotope measurements.

Edited by: K. Küsel

\section{References}

Ågren, G. I., Bosatta, E., and Balesdent, J.: Isotope discrimination during decomposition of organic matter: A theoretical analysis, Soil Sci. Soc. Am. J., 60, 1121-1126, 1996.

Åkerman, J. H. and Johansson, M.: Thawing Permafrost and Thicker Active Layers in Sub-arctic Sweden, Permafr. Perigl. Proc., 19, 279-292, 2008.

Alewell, C., Giesler, R., Klaminder, J., Leifeld, J., and Rollog, M.: Stable carbon isotopes as indicators for environmental change in palsa peats, Biogeosciences, 8, 1769-1778, doi:10.5194/bg-81769-2011, 2011.

Andersson, R. A., Meyers, P., Hornibrook, E., Kuhry, P., and Mörth, C.-M.: Elemental and isotopic carbon and nitrogen records of organic matter accumulation in a Holocene permafrost peat sequence in the East European Russian Arctic, J. Quat. Sci., 27, 545-552, 2012.

Bäckstrand, K., Crill, P. M., Jackowicz-Korczyñski, M., Mastepanov, M., Christensen, T. R., and Bastviken, D.: Annual carbon gas budget for a subarctic peatland, Northern Sweden, Biogeosciences, 7, 95-108, doi:10.5194/bg-7-95-2010, 2010.

Benner, R., Fogel, M. L., Spargue, E. K., and Hodson, R. E.: Depletion of C-13 in Lignin and Its Implications for Stable Carbon Isotope Studies, Nature, 329, 708-710, 1987.

Bosiö, J., Johansson, M., Callaghan, T.V., Johansen, B., and Christensen, T.R.: Future vegetation changes in thawing subarctic mires and implications for greenhouse gas exchange - a regional assessment, Clim. Change 115, 379-398, 2012.

Broder, T., Blodau, C., Biester, H., and Knorr, K. H.: Peat decomposition records in three pristine ombrotrophic bogs in southern Patagonia, Biogeosciences, 9, 1479-1491, doi:10.5194/bg9-1479-2012, 2012.

Christensen, T. R., Johansson, T., Åkerman, H. J., Mastepanov, M., Malmer, N., Friborg, T., Crill, P., and Svensson, B. H.: Thawing sub-arctic permafrost: Effects on vegetation and methane emissions, Geophys. Res. Lett., 31, L04501, doi:10.1029/2003GL018680, 2004.

Clymo, R. S. and Bryant, C. L.: Di?usion and mass ?ow of dissolved carbon dioxide, methane, and dissolved organic carbon in a 7-m deep raised peat bog, Geochimica et Cosmochimica Acta, 72, 2048-2066, 2008.

de Jong, R., Blaauw, M., Chambers, F. M., Christensen, T. R., de Vleeschouwer, F., Finsinger, W., Fronzek, S., Johansson, M., Kokfelt, U., Lamentowicz, M., LeRoux, G., Mauquoy, D., Mitchell, E. A. D., Nichols, J.E., Samaritani, E., and van Gell, B.: Climate and Peatlands, edited by: Dodson, J., Changing Climates, Earth Systems, and Society, Springer, Heidelberg, 85$121,2010$.
Dorrepaal, E., Toet, S., van Logtestijn, R. S. P., Swart, E., van de Weg, M. J., Callaghan, T. V., and Aerts, R.: Carbon respiration from subsurface peat accelerated by climate warming in the subarctic, Nature, 460, 616-619, 2009.

Esmeijer-Liu, A. J., Kürschner, W. M., Lotter, A. F., Verhoeven, J. T. A., and Goslar, T.: Stable Carbon and Nitrogen Isotopes in a Peat Profile Are Influenced by Early Stage Diagenesis and Changes in Atmospheric $\mathrm{CO}_{2}$ and N Deposition, Water Air Soil Pollut, 223, 2007-2022, 2012.

Fronzek, S., Luoto, M., and Carter, T. R.: Potential effect of climate change on the distribution of palsa mires in subarctic Fennoscandia, Clim. Res., 32, 1-12, 2006.

Fronzek, S., Carter, T. R., Räisän, J., Ruokolainen, L., and Luoto, M.: Applying probabilistic projections of climate change with impacts models: a case study for sub-arctic palsa mires in Fennoscandia, Clim. Change, 99, 515-534, 2010.

Gorham, E.: Northern Peatlands: Role in the Carbon Cycle and Probable Response to Climate Warming, Ecol. Appl., 1, 182195, 1991.

Hornibrook, E. R. C., Longstaffe, F. J., Fyfe, W. S., and Bloom, Y.: Carbon-isotope ratios and carbon, nitrogen and sulfur abundance in flora and soil organic matter from a temperate-zone bog and march, Geochem. J., 34, 237-245, 2000.

Johansson, T., Malmer, N., Crill, P. M., Friborg, T., Åkerman, J. H., Mastepanov, M., and Christensen, T. R.: Decadel vegetation changes in a northern peatland, greenhouse gas fluxes and radiative forcing, Glob. Change Biol., 12, 2352-2369, 2006.

Jones, M. C., Peteet, D. M., and Sambrotto, R.: Late-glacial and Holocene $\delta^{15} \mathrm{~N}$ and $\delta^{13} \mathrm{C}$ variation from a Kenai Peninsula, Alaska peatland, Paleogeogr. Paleoclimatol. Paleoecol., 293, 132-143, 2010.

Joosten, H. and Clarke, D.: The wise use of mires and peatlands - Background and principles including a framework for decision-making, in: International Mire Conservation Group and International Peat Society (eds.) NHTS Ltd, Devon, UK, available online at: http://www.imcg.net/docum/WUMP_Wise_Use_ of_Mires_and_Peatlands_book.pdf, 2002.

Jungkunst, H. F., Krüger, J. P., Heitkamp, F., Erasmi, S., Fiedler, S., Glatzel, S., and Lal, R.: Accounting more precisely for peat and other soil carbon resources, in: Recarbonization of the biosphere - ecosystems and the global carbon cycle, edited by: Lal, R., Lorenz, K., Hüttl, R. F. J., Schneider, B. U., and von Braun, J., Springer, Amsterdam, 127-157, 2012.

Keuper, F., van Bodegom, P. M., Dorrepaal, E., Weedon, J. T., van Hal, J., van Logtestijn, R. S. P., and Aerts, R.: A frozen feast: thawing permafrost increases plant-available nitrogen in subarctic peatlands, Glob. Change Biol., 18, 1998-2007, 2012.

Klaminder, J., Yoo, K., Rydberg, J., and Giesler, R.: An explorative study of mercury export from a thawing palsa mire, J. Geophys. Res.-Biogeosci., 113, 1-9, 2008.

Kokfelt, U., Reuss, N., Struyf, E., Sonesson, M., Rundgren, M., Skog, G., Rosen, P., and Hammarlund, D.: Wetland development, permafrost history and nutrient cycling inferred from late Holocene peat and lake sediment records in subarctic Sweden, J. Paleolimnol., 44, 327-342, 2010.

Krull, E. S. and Retallack, G. J.: $\delta^{13}$ C depth profiles from paleosols across the Permian-Triassic boundary: Evidence for methane release, Geol. Soc. Am. Bull., 112, 1459-1472, 2000. 
Kuhry, P. and Vitt, D. H.: Fossil carbon/nitrogen ratios as a measure of peat decomposition, Ecology, 77, 271-275, 1996.

Lal, R.: Carbon sequestration, Philosophical transactions of the royal society B, Vol. 363, (August), 815-830, 2008.

Lemke, P., Ren, J., Alley, R. B., Allison, I., Carrasco, J., Flato, G., Fujii, Y., Kaser, G., Mote, P., Thomas, R. H., and Zhang, T.: Observations: Changes in Snow, Ice and Frozen Ground, in: Climate Change 2007: The Physical Science Basis. Contribution of Working Group I to the Fourth Assessment Report of the Intergovernmental Panel on Climate Change, eidted by: Solomon, S., Qin, D., Manning, M., Chen, Z., Marquis, M., Averyt, K. B., Tignor, M., and Miller, H. L., Cambridge University Press, Cambridge, United Kingdom and New York, NY, USA, 337-384, 2007.

Lund, M., Christensen, T. R., Mastepanov, M., Lindroth, A., and Ström, L.: Effects of $\mathrm{N}$ and $\mathrm{P}$ fertilization on the greenhouse gas exchange in two northern peatlands with contrasting $\mathrm{N}$ deposition rates, Biogeosciences, 6, 2135-2144, doi:10.5194/bg-62135-2009, 2009.

Luoto, M. and Seppälä, M.: Modelling the Distribution of Palsas in Finnish Lapland with Logistic Regression and GIS, Permafrost Periglac. Process., 13, 17-28, 2002.

Luoto, M. and Seppälä, M.: Thermokarst Ponds as Indicators of the Former Distribution of Palsas in Finnish Lapland, Permafrost Periglac. Process., 14, 19-27, 2003.

Luoto, M., Heikkinen, R. K., and Carter, T. R.: Loss of palsa mires in Europe and biological consequences, Environ. Conserv., 31, 30-37, 2004.

Malmer, N. and Holm, E.: Variation of the C/N-Quotient of Peat in Relation to Decomposition Rate and Age Determination with 210 PB, Oikos, 43, 171-182, 1984.

Malmer, N. and Wallén, B.: Peat formation and mass balance in subarctic ombrotrophic peatlands around Abisko, northern Sweden, Ecol. Bullet., 45, 79-92, 1996.

Malmer, N., Johansson, T., Olsrud, M., and Christensen, T. R.: Vegetation, climate changes and net carbon sequestration in a NorthScandinavian subarctic mire over 30 years, Glob. Change Biol., 11, 1895-1909, 2005.

Marushchak, M. E., Pitkämäki, A., Koponen, H., Biasi, C., Seppälä, M., and Martikainen, P. J.: Hot spots for nitrous oxide emissions found in different types of permafrost peatlands, Glob. Change Biol., 17, 2601-2614, 2011.

Menot, G. and Burns, S. J.: Carbon isotopes in ombrogenic peat bog plants as climatic indicators: calibration from altitudinal transect in Switzerland, Org. Geochem., 32, 233-245, 2001.

Nadelhoffer, K. F. and Fry, B.: Controls on natural ${ }^{15} \mathrm{~N}$ and ${ }^{13} \mathrm{C}$ abundance in forest soil organic matter, Soil Sci. Soc. Am. J., 52, 1633-1640, 1988.
Olefeldt, D. and Roulet, N. T.: Effects of permafrost and hydrology on the composition and transport of dissolved organic carbon in a subarctic peatland complex, J. Geophys. Res., 117, G01005, doi:10.1029/2011JG001819, 2012.

Olefeldt, D., Roulet, N. T., Bergeron, O., Crill, P., Bäckstrand, K., and Christensen, T. R.: Net carbon accumulation of a high-latitude permafrost palsa mire similar to permafrost-free peatlands, Geophys. Res. Lett., 39, L03501, doi:10.1029/2011GL050355, 2012.

Pengerud, A., Cécillon, L., Johnsen, L. K., Rasse, D. P., and Strand, L. T.: Permafrost Distribution Drives Soil Organic Matter Stability in a Subarctic Palsa Peatland, Ecosystems, 16, 934-947, 2013.

Price, G. D., McKenzie, J. E., Pilcher, J. R., and Hoper, S. T.: Carbon-isotope variation in Sphagnum form hummock-hollow complexes: Implication for Holocene climate reconstruction, Holocene, 7, 229-233, 1997.

Repo, M. E., Susiluoto, S., Lind, S. E., Jokinen, S., Elsakov, V., Biasi, C., Virtanen, T., and Martikainen, P. J.: Large $\mathrm{N}_{2} \mathrm{O}$ emissions from cryoturbated peat soils in tundra, Nat. Geosci., 2, 189-192, 2009.

Rydberg, J., Klaminder, J., Rosen, P., and Bindler, R.: Climate driven release of carbon and mercury from permafrost mires increases mercury loading to sub-arctic lakes, Sci. Total Environ., 408, 4778-4783, 2010.

Schaub, M. and Alewell, C.: Stable carbon isotopes as an indicator for soil degradation in an alpine environment (Urseren Valley, Switzerland), Rapid Commun. Mass Spectrom., 23, 1499-1507, 2009.

Schuur, E. A. G., Vogel, J. G., Crummer, K. G., Lee, H., Sickman, J. O., and Osterkamp, T. E.: The effect of permafrost thaw on old carbon release and net carbon exchange from tundra, Nature, 459, 556-559, 2009.

Seppälä, M.: Surface abrasion of palsas by wind action in Finnish Lapland, Geomorphology, 52, 141-148, 2003.

Seppälä, M.: Palsa mires in Finland, in: The Finnish Environment 23/2006, Lindholm, T. and Heikkilä, R., 155-162, 2006.

Tarnocai, C., Canadell, J. G., Schuur, E. A. G., Kuhry, P., Mazhitova, G., and Zimov, S.: Soil organic carbon pools in the northern circumpolar permafrost region, Global Biogeochem. Cy., 23, GB2023, doi:10.1029/2008GB003327, 2009.

Turetsky, M. R.: Decomposition and Organic Matter Quality in Continental Peatlands: The Ghost of Permafrost Past, Ecosystems, 7, 740-750, 2004.

Yu, Z., Beilman, D. W., Frolking, S., MacDonald, G. M., Roulet, N. T., Camill, P., and Charman, D. J.: Peatlands and Their Role in the Global Carbon Cycle, EOS, 92, 97-98, 2011. 